\title{
Hebei Province Qing County Straw Partnerships Biogas Research Application and Promotion Research
}

\author{
$\mathrm{Die} \mathrm{Hu}$ \\ North China Electric Power University \\ Baoding, Hebei,China \\ e-mail: $1772654961 @ q q . c o m$
}

\begin{abstract}
As the improvement of the condition of our country's economy and the development of urban and rural areas as a whole, The rural biogas construction also presents the diversified development trend.This paper introduces the hebei qingxian county straw partnerships biogas application status,For straw partnerships biogas development train of thought.
\end{abstract}

Keywords-Strawbiogas;Partnerships;biogas;application;de velopment

\section{INTRODUCTION}

Straw partnerships biogas engineering technology is the crop straw as the main raw material,using the anaerobic fermentation technology for making biogas,access to energy and control environmental pollution of rural energy engineering. With the rapid development of economy in our country,integration of urban and rural development to speed up the pace,the use of straw biogas engineering technicians in the straw utilization, The use of straw biogas engineering technicians in the straw utilization. This paper introduces the hebei county straw biogas partnerships gas supply technology application status, at the same time also for straw partnerships in China provides a train of thought in the promotion of biogas in rural areas

\section{THE RESEARCH BACKGROUND AND PROBLEMS}

A The shortage of Conventional Energy Sources and Energy Consumption Demand Imbalance.

With the improvement of China's GDP, per capita GDP has been in many parts of the equivalent to the level of moderately developed countries, which looking from the international development experience, When the per capita GDP of about $\$ 5000$,Energy consumption will be explosive growth.Led to the contradiction between resource environmental bearing capacity and economic development is increasingly prominent,energy conservation and emissions reduction task is very heavy.Currently, The rapid economic development of our country, The contradiction between energy supply and consumption is particularly prominent.

$B \quad$ The Haze Weather Situation of the Growing

Integration of the Beijing-tianjin-hebei Region

Development

In recent years, our country increasingly frequent of haze weather not only severely affected the physical and mental health of the residents and caused great trouble to the broad masses of people's production and living, but also affected the image of our country and city image shaping.Compared with a national haze weather seriously in the top 10 cities in hebei province is seven.2013 environmental protection based on air quality monitoring results show that the beginning and the end of the year in 2013 across great river north and south of the country's two long duration, and degree of depth, spread to a wide area of the fog, the pollution of heavy area of beijing-tianjin-hebei and its surrounding cities, especially in southern hebei, shijiazhuang and xingtai city is the most polluted cities.

Mounting haze weather will, green low carbon energy saving and emission reduction, and ecological civilization construction to a new climax.As the haze of big province,also plays an important role in the building of the beijing-tianjin-hebei urban circle integration China's hebei province,Away from the fog haze weather, the control environmental pollution of a long work.And released by straw burning smoke is an important cause of the haze,implementation of straw biogas can greatly reduce the straw combustion caused by air pollution.

$C \quad$ The need of new rural construction in our country

Rural biogas construction not only has direct economic benefits, but also has good social benefit and ecological benefit, in our country at present to develop in the construction of new socialist countryside has a vital position.Through the use of biogas,improve the living environment, effectively consolidate the role of ecological construction. After biogas purification, can be a natural gas and carbon dioxide to a wider range of applications, more improve the efficiency and use scope of biogas.Renewal biogas slurry into organic fertilizer to promote pollution-free agricultural production and improve agricultural products quality is very good also, at the same time also can promote the farmers' income.In addition, through developing biogas technology application promotion, is a good way to solve the farmers daily energy consumption is too big and parts of rural life energy shortage problem., improve farmers' living standards, improve rural environmental sanitation.

\section{PARTNERSHIPS BIOGAS RESEARCH STATUS}

Overseas research for partnerships biogas is earlier than in China,Soren Tafdrup (1994) analyzed the Denmark partnerships biogas agriculture and the benefits of the natural environment and save energy, which is more cheap, environmental protection, low consumption of energy,but the public investment is needed to solve its funding problems, prompting them to use for lon.Orrit Gosens (2012) analyzed the continuous function of biogas is beneficial to environmental protection and energy supply,But for its subsequent development, cannot leave the support of the government policy, 
funding.Guizhen He (2013) are analyzed using a centralized and a decentralized (household) biogas economic and technical value and sustainable,think the construction and utilization of biogas system should consider the local natural conditions, economic, social,to determine its final should take the form of.Hongyan $\mathrm{Lu}$ (2013) after the on-the-spot investigation,think partnerships biogas can protect the local environment and clim,provide fertilizer can be recycled,Biogas project at the same time also can affect farmers and investment company,even the local government, policy guidance is required to develop the industry.

Our partnerships biogas later than type household biogas rise time,Some scholars aiming at the existing problem of household biogas,Li Changwei (2010) study of hebei to vigorously promote partnerships biogas are pointed out.NiDan into (2011) from the aspects of technology, society, economy three analyzes the feasibility of implementing partnerships biogas,think partnerships methane than traditional household biogas scale degree is high, the capital source channel, management more convenient, farmers accept degree is high,Wider implementation and promotion prospects. For the study on the model of combined gas supply partnerships,.For the study of the patterns of gas supply of partnerships,Hai-song huang (2010) identified four specific pattern of partnerships:Gas supply mode in parallel;Series air supply mode;Series-parallel mixed gas supply mode;Scattered radiation air supply mode,For the difference of terrain, the village can be done in terms of different choice.In addition,Hai-song huang (2010) introduced the guizhou province rural small partnerships is pointed out that farmers can to take a breath, per cubic meters for methane gas fee directly,to run the market.

From what has been discussed above,the attention of scholars for partnerships biogas started late,the related research is less.Only part of the study is mostly argument partnerships biogas relative to the advantage of household biogas as well as the feasibility of its implementation and so on.Partnerships biogas promotion value and future development prospect has been most scholars, but for how to further promote partnerships biogas, the related research is rarely involved.

qing county, hebei province partnerships biogas application status.China's rural household biogas large-scale construction began in the late $1950 \mathrm{~s}$,Biogas construction in hebei province has been walking in the forefront.Starting in 2006, On the content of the rural biogas construction in hebei province are adjusted and try,combined with the new countryside, new residential construction, innovation introduced a "new residents low carbon green life style".As of 2011, The province has built partnerships biogas 14,now supply 15000 households.And this among them,Qing county in hebei province biogas development is particularly prominent.

In recent years, Qing county of biogas model has experienced from the "household biogas" to "partnerships biogas development process.In 2008, Qing county has built the largest pure straw gas station.As of 2010,The county has built geng GuanTun Village, east village, but lack of tuen mun village, Chen village, fan GuanTun Village Wang Shengwu the chariot five village straw methane and gas centralized supply,Is now preparing yan zhuang zi straw biogas engineering. The county fermenter total volume of $7200 \mathrm{~m} 3$, Five village biogas en,digest fresh body straw 24000 tons, It can produce methane 3.15 million $\mathrm{m} 3$,can meet the 8000 households gas and increase savings income 8 million yuan.

Legal department of the university of north China electric power group in December 2014 and January 2015 in cangzhou qingxian county geng GuanTun Village issuing questionnaires.This research will geng GuanTun Village as our research site, the villagers of GengGuanTun research.We use a structured questionnaire to fill out and supplemented by the form of the interview,completed the questionnaire after recycling.A questionnaire of this study were to geng GuanTun Village people 110,recycling effective questionnaire 102 copies, Questionnaire recovery was $92.72 \%$.This investigation and basic information from the villagers, the villagers partnerships biogas using the basic situation, the use of partnerships biogas three aspects of the influence of the villagers' lives,content coverage, high efficient, questionnaire data obtained have high reliability and validity.

Due to the theme of this research is to investigate the partnerships biogas satisfaction,Analysis we selected the partnerships biogas is satisfaction as explained variable, the basic information, the villagers partnerships biogas using the basic situation, the use of partnerships biogas influence on villagers' life of three aspects: 23 variables as explanatory variables as the theme of this research is to investigate the partnerships biogas satisfaction,to explain on partnerships biogas satisfaction.

TABLE I. Be explained variable basic statistical description

\begin{tabular}{|c|c|c|}
\hline $\begin{array}{c}\text { Your satisfaction of } \\
\text { partnerships biogas }\end{array}$ & frequency & frequency (\%) \\
\hline Not satisfied with & 3 & 2.94 \\
\hline less-than-desirable & 15 & 14.71 \\
\hline ordinary & 36 & 35.29 \\
\hline satisfaction & 33 & 32.35 \\
\hline quite satisfied & 15 & 14.71 \\
\hline Total & 102 & 100.00 \\
\hline
\end{tabular}

Table 1 illustrates that,Be explained variable "your satisfaction" of partnerships biogas more obvious differences in distribution.Data analysis according to the results,in all participants in the survey the villagers, $14.71 \%$ of the villagers said satisfied with partnerships biogas,32.35\% of the villagers said satisfied with partnerships biogas,35.29 the villagers said the partnerships biogas satisfaction, While $14.71 \%$ of the villagers said less-than-desirable, $2.94 \%$ of the villagers said Not satisfied with this.

\section{QING COUNTY, HEBEI PROVINCE STRAW}

\section{PARTNERSHIPS BIOGAS MODEL OF THE PROMOTION}

In practice,Household biogas has exposed the disadvantages of its development,as in the management and maintenance of the late household biogas use need more labor force;Use and maintenance of household biogas need to invest more costs;family don't want to burden and a series of problems.In the process of research to solve the household biogas,experts put forward 
opinions for the development of partnerships biogas,after practice has obtained the very good effect,and presented the strong momentum of development.In order to promote partnerships biogas,also need the government to increase policy support, capital support, social publicity, experts and scholars of innovation, technology and development mode.By make full use of biogas, to achieve energy conservation and emissions reduction, low carbon environmental protection purposes.

A Strengthen the Policy Support and Funding

The foundation of perfecting the policy of promoting partnerships biogas.Affirmation of the role of government for partnerships biogas, formulate the partnerships biogas development policy and the train of thought, to guide local actual construction, to play to the role of the escort policy, make scientific planning, adjust measures to local conditions.Partnerships biogas promotion should strengthen government guidance, the formation of multiple input pattern,According to "the government support, market operation, attach importance to both farmer main body, connecting the construction mechanism to promote the development of partnerships biogas,actively improve the relevant policies and regulations.

Government policy support, the core is to strengthen financial capital investment.The central government subsidies to improve partnerships biogas construction standard, the local government should strengthen financial support form a complete set to formulate corresponding policies to raise funds through various channels, increase the investment.

$B$ to Strengthen the Publicity

To give full play to the role of the policy, strive for the social from all walks of life support.Understand the benefits of partnerships biogas to farmers. Through radio, television, newspapers and other media, to promote the use of partnerships biogas and follow-up service and guidance,improve the social awareness of partnerships biogas,let users understand the partnerships biogas and using biogas.

First of all, we must strengthen the propaganda, environmental protection and propaganda education of the rural ecological environment.To vigorously promote rural grassroots cadres and masses of ecological deterioration of the dangers of farmers' living environment and the important and urgency of strengthening the rural ecological environment protection,increasing peasants take the initiative to maintain their own living environment and ecological consciousness of rights and interests, form the integral atmosphere of the rural ecological environment protection, which can effectively reduce promoting partnerships biogas resistance, but also can improve their willingness to use biogas.

And then to enhance the promotion of comprehensive utilization of biogas.let the village and household biogas engineering, the real service for the populace,to make significant channel started the work.NengYuanBan using county, the county agricultural extension extending stations, villages and towns agricultural technical service force, the partnerships biogas comprehensive benefit of the propaganda,specially for successfully using partnerships biogas demonstration area, can take videos, feature films, news, etc.,Understanding of partnerships biogas development to farmers,actively guide farmers to use partnerships biogas.Widely mobilize farmers, to organize the masses to actively join the service organization, give play to the subjective initiative of farmers, strengthen team strength, promote rural partnerships biogas socialization, the property management.

\section{Innovation Partnerships Biogas Development \\ Pattern}

Partnerships methane plays a scale effect, avoid the household biogas resources waste problem,How should to partnerships biogas joint?The late management how to efficiently carry out?Region is different also can undertake mode innovation, but should adhere to the "government-led, diverse participation, diverse ways" and the principle of "professional service, property management",Establishing and perfecting the rural service network based, farmers, service personnel as the backbone, linking up and down, left and right sides is linked together, complete functions, efficiency and service quality of the rural partnerships biogas property management service system, promote the diversified development of partnerships biogas.

For partnerships biogas follow-up service system should introduce market mechanisms, under the government guidance, and gradually establish a open, equal and competitive market environment,At the same time, continuously broaden the service areas, with biogas as link, make full use of the role of biogas slurry, renewal in agricultural production, giving impetus to the development of planting, breeding, The financing service station, you can take on the premise of guarantee the quality of network service, reasonable determination of the pay of farmers service charge; At the same time, the municipal department in charge of energy actively to the municipal finance and the business department for subsidies.

\section{Strengthen the Partnerships Biogas Technology Research and Development}

Partnerships biogas is bigger, the higher levels to the requirement of related equipment, which requires strengthening partnerships biogas technology research.and biogas also has certain risk, to ensure the healthy development of partnerships biogas, wants to concentrate on technology, design, material, construction, to the national support project material purchasing must strictly implement national and provincial related technical standards, gas cookers and other key equipment should all through the government public bidding procurement.

Promotion of biogas in construction process, will encounter a series of problems, such as how to overcome the north pool of the problem of short life requires strengthening the construction of the biogas technology research and use technology.In order to prolong the life time of the methane effectively, and improve the utilization rate, need to increase the heat preservation facilities, this is about to have the corresponding technology to support.How to reduce the construction cost of biogas digester, related technical support also want to have.By strengthening partnerships biogas technology research and application of technology 
innovation and development, to speed up the pace of transformation of scientific and technological achievements, greatly improve the technology level of resource saving and recycling.

\section{REFERENCES}

[1] Sòren Tafdrup.Centralized biogas plants combine agricultural and environmental benefits with energy production[J].Water Science and Technology,1994,30(12):133-14

[2] Jorrit Gosens, Yonglong Lu,Guizhen He,Bettina Bluemling,Theo A.M. Beckers.Sustainability effects of household-scale biogas in rural China[J].Energy Policy,2013,54:273-287.

[3] Guizhen He,Bettina Bluemling,Arthur P.J. Mol,Lei Zhang,Yonglong Lu.Comparing centralized and decentralized bio-energy systemsin rural China[J].Energy Policy,2013,63:34-43.

[4] Hongyan Lu,Jiong Yan,Bing Xue, Peter Heck.Cooperation Challe nges of Developing Centralized Biogas Plant in China -A Material Flow Management Approach[J]. International Journal of Energy Science, 2013,3(2):60-69.
[5] Changwei Li.Hebei methane application research.[D].Beijing,China academy of agricultural sciences, 2010.

[6] NiDan, tiky. Rural partnerships biogas project feasibility study and the experience - jiangshan city, zhejiang province, silt head town, for example [J]. Journal of China environmental protection industry, 2010, (4) : 13 to 17.

[7] Hai-song huang, Yuan Sen Zhao Limei. Guizhou province rural small biogas project partnerships gas supply model to explore the [J]. Journal of Chinese agricultural mechanization, 2010, (2) : 52-54,59.

[8] Zhu Junping Huang Zhenxia, Zou Chang we Jiang Yinghua, WuYuGuang. Ji county rural small biogas projects focus (partnerships) air supply mode [J]. China biogas, 2008, 26 (1) : 34-36.

[9] NiDan, tiky. Rural partnerships biogas project feasibility study and the experience - jiangshan city, zhejiang province, silt head town, for example $[\mathrm{J}]$. Journal of China environmental protection industry, 2010, (4) : 13 to 17.

[10] KuangJing Zhang En and, Chen bing. Partnerships biogas engineering economic and environmental benefits evaluation [J]. China agriculture bulletin, 2011, 27 (4) : 401-405. 